This is the accepted manuscript version of the journal article, which is made available for scholarly purposes only, in accordance with the journal's author permissions. The final publication is available at http://link.springer.com. The full citation is:

Milledge JJ and Heaven S (2013) A review of the harvesting of micro-algae for biofuel production. Reviews in Environmental Science and Biotechnology 12, 165-78. http://dx.doi.org/10.1007/s11157-012-9301-z 


\section{A Review of the Harvesting of Micro-algae for Biofuel Production}

\section{John J Milledge* and Sonia Heaven}

Engineering and the Environment, University of Southampton, *email

\section{j.milledge@soton.ac.uk}

Acknowledgement -This work was partially supported by the EU FP7 ALL-GAS project (268208).

\section{Introduction}

Although algal biomass can be 'energy rich', the growth of algae in dilute suspension at around $0.02 \%-0.05 \%$ dry solids (Zamalloa et al. 2011) poses considerable challenges in achieving a viable energy balance in algal process operations. Additional challenges of algae harvesting come from the small size of micro-algal cells (most algae are below 30 $\mu \mathrm{m}$ ) (Molina Grima et al. 2003); the similarity of density of the algal cells to the growth medium (Reynolds 1984); the negative surface charge on the algae that results in dispersed stable algal suspensions, especially during the growth phase (Edzwald 1993; Moraine et al. 1979; Packer 2009); and the algal growth rates which require frequent harvesting compared to terrestrial plants .

The cost effective harvesting of micro-algae is considered to be the most problematic area of algal biofuel production (Greenwell et al. 2010) and a key factor limiting the commercial use of micro-algae (Olguín 2003). It has been suggested that 20 to $30 \%$ of the costs of micro-algal biomass is due to the costs of harvesting (Mata et al. 2010; Molina Grima et al. 2003; Verma et al. 2010), but estimates as high as $50 \%$ of micro-algal biomass cost have been given (Greenwell et al. 2010). It has been estimated that $90 \%$ of the equipment cost for algal biomass production in open systems may come from harvesting and dewatering (Amer et al. 2011). The need for continuous harvesting of the dilute suspension makes the harvesting of micro-algae 'inherently more expensive' than harvesting land plants (Benemann et al. 1977), and the separation of micro-algae by settlement and centrifugation can have a harvesting energy requirement of $1 \mathrm{MJ}$ $\mathrm{kg}^{-1}$ of dry biomass, greater than the energy cost of harvesting wood at $0.7-0.9$ $\mathrm{MJ} \mathrm{kg}^{-1}$ (Sawayama et al. 1999). The cost of harvesting micro-algae needs to be 
reduced. Unfortunately a recent report by UK's Biotechnology and Biological Sciences research council (BBSRC) on algal research has concluded that: "hardly any commercial activity exists in downstream processing"(Schlarb-Ridley 2011). Most work on micro-algal species selection for biofuel production has been focused on yield and composition rather than on ease of recovery (Brennan and Owende 2010).

Table 1 Comparison of microalgal harvesting methods (Mohn 1988; Molina Grima et al. 2003; Shen et al. 2009)

\begin{tabular}{|c|c|c|c|}
\hline & Advantages & Disadvantages & $\begin{array}{l}\text { Dry Solids } \\
\text { Output } \\
\text { Conc' }\end{array}$ \\
\hline Centrifugation & $\begin{array}{l}\text { Can handle most algal types with rapid efficient cell } \\
\text { harvesting. }\end{array}$ & High capital and operational costs. & $10-22 \%$ \\
\hline Filtration & Wide variety of filter and membrane types available. & $\begin{array}{l}\text { Highly dependent on algal species; best suited to } \\
\text { large algal cells. Clogging or fouling an issue. }\end{array}$ & $2-27 \%$ \\
\hline Ultrafiltration & Can handle delicate cells. & High capital and operational costs & $1.5-4 \%$ \\
\hline Sedimentation & $\begin{array}{l}\text { Low cost, potential for use as a first stage to reduce } \\
\text { energy input and cost of subsequent stages. }\end{array}$ & $\begin{array}{l}\text { Algal species specific, best suited to dense non- } \\
\text { motile cells. Separation can be slow. Low final } \\
\text { concentration. }\end{array}$ & $0.5-3 \%$ \\
\hline Chemical Flocculation & $\begin{array}{l}\text { Wide range of flocculants available, price varies } \\
\text { although can be low cost. }\end{array}$ & Removal of flocculants, chemical contamination. & $3-8 \%$ \\
\hline Flotation & $\begin{array}{l}\text { Can be more rapid than sedimentation. Possibility to } \\
\text { combine with gaseous transfer. }\end{array}$ & $\begin{array}{l}\text { Algal species specific. High capital and operational } \\
\text { cost. }\end{array}$ & $7 \%$ \\
\hline
\end{tabular}

Algae can be harvested by a number of methods; Sedimentation, Flocculation, Flotation, Centrifugation and Filtration or a combination of any of these. Despite the importance of harvesting to the economic and energy balance viability of micro-algal biofuel, however, there is no universal harvesting method for microalgae (Mata et al. 2010; Shen et al. 2009). A recent extensive review of dewatering micro-algal cultures concluded that "currently there is no superior method of harvesting and dewatering" (Uduman et al. 2010). A summary of advantages and disadvantages of the various methods to harvest micro-algae is given in Table 1(Milledge and Heaven 2011).

The final moisture content of the harvested algal biomass is an important criterion in the selection of the harvesting method (Molina Grima et al. 2003). Micro-algal biomass can spoil in hours if the moisture content is greater than $85 \%$ (Mata et al. 2010) and high moisture content can have a substantial influence on the costs and methods of further processing (Molina Grima et al. 2003) and energy extraction from the biomass.

\section{Sedimentation}


In sedimentation gravitational forces cause liquid or solid particles to separate from a liquid of different density, but the process can be extremely slow especially if density difference or particle size is small. Sedimentation can be described by Stokes' Law which assumes that sedimentation velocity is proportional to the square of the (Stokes') radius of the cells and the difference in density between the micro-algal cells and the medium as shown below:

$$
\text { Settling velocity }=\frac{2}{9} g \frac{r^{2}}{\eta}\left(\rho_{s}-\rho_{l}\right) \quad \text { (Equation 1) }
$$

where $r$ is cell radius, $\eta$ is fluid dynamic viscosity and $\rho_{s}$ and $\rho_{1}$ are the solid and liquid densities.

The density of micro-algae is close to that of water and of salt water at $1024.7 \mathrm{~kg}$ $\mathrm{m}^{-3}$ (Millero and Lepple 1973) and therefore there is little density difference driving micro-algal settlement. The cytoplasm of marine micro-algae has a density between 1030 and $1100 \mathrm{~kg} \mathrm{~m}^{-3}$ (Smayda 1970), the density of cyanobacteria is between 1082 and $1104 \mathrm{~kg} \mathrm{~m}^{-3}$ (Kromkamp and Walsby 1990), density of marine diatom and dinoflagellates between 1030 and $1230 \mathrm{~kg} \mathrm{~m}^{-3}$ and the density of the freshwater green microalgae (Chlorococcum) between 1040 and $1140 \mathrm{kgm}^{-3}$ (Van Lerland and Peperzak 1984).

A settlement velocity of $0.1 \mathrm{~m}^{-1} \mathrm{y}^{-1}$ can be calculated using Stokes' Law (equation 1) for a common spherical shaped micro-algae, Chlorella (density 1070 $\mathrm{kg} \mathrm{m}^{-3}$ and average cell diameter $5 \mu \mathrm{m}$ (Edzwald 1993)), in freshwater (density at

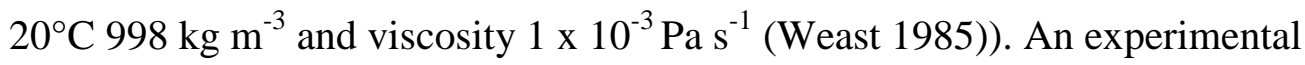
study found a considerably higher settling rate for Chlorella at $3.6 \mathrm{~m} \mathrm{day}^{-1}$ (Collet et al. 2011), but Chlorella does not normally settle readily (Nurdogan and Oswald 1996). The calculated settlement velocity of Cyclotella, a similar sized alga to Chlorella, is $0.04 \mathrm{~m} \mathrm{day}^{-1}$, but the observed settlement rate was higher at $0.16 \mathrm{~m}$ day $^{-1}$ (Smayda 1970). The observed sinking rates of micro-algae have been found to deviate from calculated rates, being up to several times higher or lower than the calculated rate (Reynolds 1984; Smayda 1970). The settling velocity is very dependent upon the type of micro-algae present, but average settling velocity of $0.2 \mathrm{~m} \mathrm{day}^{-1}$ for diatoms, $0.1 \mathrm{~m} \mathrm{day}^{-1}$ for green micro-algae and $0.0-0.05 \mathrm{~m} \mathrm{day}^{-1}$ for cyanobacteria have been suggested for water quality models (Cole and Wells 1995). 
Stokes' law holds for spheroid shapes, but micro-algae are most often not spherical (Peperzak et al. 2003). Micro-algae can have a diverse range of shapes, a fact that is often suggested as an evolutionary development to prevent settling from the euphotic zone (Smayda 1970; Sournia 1978). The sinking rate of 24 autotrophic micro-algae ranging in size from under 10 to $1000 \mu \mathrm{m}$ was found to be between -0.4 to over $2.2 \mathrm{~m} \mathrm{day}^{-1}$ with an average of $0.6 \mathrm{~m} \mathrm{day}^{-1}$, but no straightforward correlation was found between size and sinking rate and no relationship was found between cell size and sinking rates for diatoms (Peperzak et al. 2003). In a study of 20 micro-algae only four always settled readily, although 14 settled out occasionally (Peperzak et al. 2003). In a study of 30 species of micro-algae found in wastewater most were found reluctant to settle, with needle like or long cylindrical micro-algae being particularly resistant to settling (Choi et al. 2006). Filamentous algae (Spirulina) and colonial algae (Micractinim, Scenesdesmus) with a cluster diameter of $\sim 60 \mu \mathrm{m}$ have been shown to be harvestable by settlement, but smaller algae (Chlorella) and motile microalgae (Euglena, Chlorognium) do not readily settle out of suspension (Nurdogan and Oswald 1996). Dinoflagellates have been found to be able to swim at speeds of up to $0.03 \mathrm{~m} \mathrm{~min}^{-1}$ (Smayda 1970) and many species of micro-algae have been shown to move upwards towards light (Kromkamp and Walsby 1990; Smayda 1970; Sournia 1978).

The settlement of micro-algae varies between species, but can also alter within the same species. Settlements rates have been shown to vary with light intensity (Waite et al. 1992), nutrient deficiency has been shown to decrease settlement rate (Bienfang 1981) and sinking rate increases in older cells especially in senescent cells (non-dividing cells between maturity and death) (Smayda 1970) and sporeproducing cells (Bienfang 1981). The average density of carbohydrate is $1500 \mathrm{~kg}$ $\mathrm{m}^{-3}$, protein $1300 \mathrm{~kg} \mathrm{~m}^{-3}$ and lipid $860 \mathrm{~kg} \mathrm{~m}^{-3}$ (Reynolds 1984), and micro-algae with a high lipid content are likely to settle less readily due to the lower density. Sedimentation has not been widely used for separation of micro-algae (Uduman et al. 2010) and although settling has been demonstrated in pilot-scale wastewater treatment systems (Lundquist et al. 2010), it has not yet been achieved on a large 
scale. The sinking rate of small micro-algae $4-5 \mu \mathrm{m}$ in the open ocean is 'insignificantly small' (Waite et al. 1992).

Cell recovery and solid concentrations are low for micro-algal settlement (Mata et al. 2010; Shen et al. 2009) with cell recoveries of 60 to $65 \%$ (Collet et al. 2011; Ras et al. 2011) and solid concentrations of up to $1.5 \%$ total suspended solids (Uduman et al. 2010). Energy consumption of settlement harvesting is generally low, with a lamella separators using $0.1 \mathrm{kWh} \mathrm{m}^{-3}$ to achieve an output concentration of 0.1 to $1.5 \%$ dry micro-algal biomass (Uduman et al. 2010; Van den Hende et al. 2011). Settlement of colonial and larger micro-algae could be useful as a pre-concentration step for use with other harvesting techniques.

\section{Flocculation}

Flocculation is normally used in conjunction with other harvesting methods (Brennan and Owende 2010). Increasing the size of particles by the aggregation of algal cells through flocculation can increase the rate of settling or flotation (Mata et al. 2010). Flocculation has been suggested as a superior method to separate algae as it can handle large quantities of micro-algal suspension and a wide range of micro-algae (Uduman et al. 2010). Flocculation has also been suggested as the most reliable and cost-effective method although unfortunately still "quite expensive" (Benemann et al. 1980). Flocculation can occur naturally in certain micro-algae, in a process known as auto-flocculation, and micro-algae may flocculate in response to environmental stress; changes in nitrogen, $\mathrm{pH}$ and dissolved oxygen (Schenk et al. 2008; Uduman et al. 2010). Auto-flocculation does not occur in all micro-algae species and can be slow and unreliable (Schenk et al. 2008). Flocculation can be induced by chemicals, both inorganic and organic, or by microorganisms; but flocculants may be algae species-specific and recovery and recycling of the flocculants can be problematic (Mohn 1988; Molina Grima et al. 2003; Oswald 1988; Shen et al. 2009). The shape, size and composition of flocs can be very diverse depending on micro-algal species and flocculant (Jago et al. 2007). An ideal flocculant should be inexpensive, nontoxic and effective in low concentrations (Molina Grima et al. 2003) and it should also preferably be derived from non-fossil fuel sources, be sustainable and renewable. 
Cyclotella, a diatom with a density of $1114 \mathrm{~kg} \mathrm{~m}^{-3}$ and an average diameter $6 \mu \mathrm{m}$, does not settle rapidly and based on a Stokes' Law calculation for removal in a conventional settler at overflow rate of $1 \mathrm{~m} \mathrm{hour}^{-1}$ the required diameter for a floc of cells at the same density would be $88 \mu \mathrm{m}$ (Edzwald 1993). Alum flocculated Cyclotella has a lower density of $1001 \mathrm{~kg} \mathrm{~m}^{-3}$ than Cyclotella cells and the floc particle diameter would need to be $210 \mu \mathrm{m}$ for settlement at $20^{\circ} \mathrm{C}$ (Edzwald 1993). Alum flocs typically range in diameter from $30 \mu \mathrm{m}$ and $400 \mu \mathrm{m}$ (Hendricks 2010). but low density algal flocs can be difficult to separate by sedimentation (Edzwald 1993).

Lime (calcium hydroxide) has been used to remove suspended solids and microalgae from wastewater since the 1920s (Oswald 1988). Multi-valent metal salts, ferric chloride, ferric sulphate, and aluminium chloride (alum) are commonly used in wastewater treatment to remove algae, and alum has been found effective in flocculating both Chlorella and Scenedesmus (Molina Grima et al. 2003). Aluminium salts have been found more effective in the flocculation of Chlorella than ferric salts (Papazi et al. 2010). Ferric salt have also been found to be inferior to alum in the flocculation of micro-algae in respect of optimal dose, $\mathrm{pH}$ and the quality of the resultant water and slurry (Shelef et al. 1984a). Dosages of nonorganic flocculants can be high at $1 \mathrm{~g} \mathrm{l}^{-1}$ (Papazi et al. 2010) and although aluminium sulphate flocculated micro-algae have been used for aquaculture feed inorganic flocculants can be toxic (Harith et al. 2009). Inorganic flocculants can also have negative effects on micro-algal viability and can colour and modify micro-algal growth media, preventing recycling and reuse (Molina Grima et al. 2003; Papazi et al. 2010; Schenk et al. 2008). Although alum and other inorganic flocculants are relatively cheap compared to some synthetic organic flocculants, the higher dosage rates required can result in a higher cost per unit of micro-algae flocculated than more expensive organic flocculants (Mohn 1988). It would appear that there is a need for an alternative to the traditional inorganic salt flocculants that are lower dose, less toxic and do not have adverse effects on growth medium recycling after flocculation.

Up to the late 1970s no polyelectrolyte flocculant effective for micro-algal effluent was available (Moraine et al. 1979), but effective polyelectrolytes were 
later found (Shelef et al. 1984a). Cationic polyelectrolytes are now considered as the most effective flocculants for the recovery of microalgae (Uduman et al. 2010). Recent research at the University of Almeria has found cationic polyelectrolytes more effective at flocculating freshwater micro-algae than metal salts, achieving high biomass concentration (concentration factor up to 35 times) at lower dosage rates of 2 to $25 \mathrm{mg} \mathrm{l}^{-1}$ (Granados et al. in press).

Magnafloc LT25, a non-ionic polymer from BASF, has been found effective in flocculating a wide range of micro-algae at an addition rate of $0.5 \mathrm{mg} \mathrm{l}^{-1}$ of algal suspension in conjunction with $\mathrm{pH}$ adjustment to 10-10.6, with micro-algal concentrations in the settled floc 200-800 times higher than in the original suspension (Knuckey et al. 2006). Magnafloc LT25 has also been found to be effective in flocculating Chaetoceros at dosage of less than $1 \mathrm{mg}^{-1}$ while maintaining high micro-algal cell viability (over 75\%)(Harith et al. 2009). Magnafloc 1957, a low molecular weight cationic resin was found to be as effective as ferric chloride in dewatering of sludge in post Auto-thermal Thermophyllic Aerated Digestion (ATAD) and Magnafloc 1957 replaced ferric chloride due to lower health safety risk at no additional operating cost at a water reclamation plant in Bendigo, Australia (Elliott 2006). Praestol, a cationic organic flocculant based on polyacrylamide, has been found to be effective at dosages of $1 \mathrm{mg}^{-1}$ in flocculating both Teraselmis and Spirulina with $70 \%$ recovery of biomass and no inhibitory effect on the micro-algal growth in the recycled growth medium after flocculation (Pushparaj et al. 1993).

Flocculants derived from renewable plant and animal materials could have environmental advantages over both inorganic flocculants and polyelectrolyte flocculants derived from fossil fuel. Chitosan, a cationic inorganic polymer derived from crustacean shells has been used in the treatment of wastewater in the food industry (Harith et al. 2009). Chitosan has been shown to be effective on a wide range of freshwater micro-algae, but dosages are considerably higher than with synthetic organic flocculants 20 to $150 \mathrm{mg} \mathrm{l}^{-1}$ (Harith et al. 2009; Molina Grima et al. 2003). Recent research at the University of Almeria has shown that chitosan was not efficient in producing flocs from Muriellopsis, with low biomass recovery and biomass concentration while requiring significantly higher dosage 
than synthetic polyelectrolytes (Granados et al. in press). No efficient flocculation was observed using only chitosan for Phaeodactylum, but 'satisfactory' flocculation results were obtained using chitosan at a dosage of $20 \mathrm{mg} \mathrm{l}^{-1}$ if the $\mathrm{pH}$ was increased to 9.9 (Şirin et al. 2012). Although chitosan is considered non-toxic (Vandamme et al. 2010), there have been reports of reduced survival of oyster larvae fed chitosan flocculated micro-algae (Molina Grima et al. 2003). The costs of chitosan and the higher dosages compared to synthetic polyelectrolytes would appear to make it uneconomic for harvesting of micro-algae for biofuel production (Vandamme et al. 2010; Mohn 1988).

Starch and modified starch can settle microalgae (Mohn 1988). Cationic starch is increasingly being used as an alternative to inorganic and synthetic organic flocculants in wastewater and paper mill industries and has been found to flocculate Scenedesmus and Parachlorella, but at higher dosages than chitosan and with a large degree of variation between effectiveness of the cationic starches tested (Vandamme et al. 2010). Starch and modified starches do not appear to affect the viability of micro-algae and have been used in the treatment of drinking water (Vandamme et al. 2010). Modified starches could be more cost-effective than both inorganic and synthetic organic flocculants (Vandamme et al. 2010; Mohn 1988), but current cationic starches are not specifically designed for microalgae and their modification to improve micro-algal performance could dramatically increase costs (Vandamme et al. 2010).

The majority of research work on flocculation has been on freshwater algae (Uduman et al. 2010) and although many species of freshwater microalgae can be successfully flocculated using organic cationic polymers salinity levels above $5 \mathrm{~g}$ $1^{-1}$ have been shown to inhibit flocculation (Knuckey et al. 2006; Molina Grima et al. 2003), while sea water typically has a salinity of $\sim 35 \mathrm{~g}^{-1}$ (Millero and Lepple 1973; Speight 2005). At high ionic strengths it is believed that polyelectrolytes tend to fold tightly and are unable to bridge between micro-algal cells to form a floc (Molina Grima et al. 2003). In marine systems the use of polyelectrolytes in conjunction with inorganic flocculants, ferric salts, alum and lime has been found to be effective (Knuckey et al. 2006; Sukenik et al. 1988), but the dosage of flocculants to flocculate marine micro-algae has been found to be 5 to 10 times 
higher than that for freshwater micro-algae (Knuckey et al. 2006; Uduman et al. 2010). The flocculant dosage required for the removal of $90 \%$ of micro-algae from suspension has been found to increase linearly with salinity as expressed in ionic strength (Shelef et al. 1984b; Sukenik et al. 1988).

Flocculation of some micro-algae can be achieved by adjustment of $\mathrm{pH}$ (Molina Grima et al. 2003; Shelef et al. 1984a). Increasing pH to 11-12 has been shown to induce flocculation in Chlorella (Ras et al. 2011), but Chlamydomonas did not flocculate readily with the addition of alkali (Schlesinger et al. in press). Extreme pH may cause micro-algal damage and death and could be unreliable and uneconomic on a commercial scale (Benemann and Oswald 1996; Lee et al. 2009). The amount of alkali required to cause flocculation of micro-algae can be lower in high density micro-algae suspensions, greater than normally found in micro-algal growth, possibly making alkaline flocculation economically viable (Schlesinger et al. in press); but a low energy pre-concentration settlement technology is required before flocculation adding extra complexity and cost. It is possible that flocculation could be achieved through other forms of environmental modification, such as nitrogen limitation; however the exact mechanisms behind environmental modification induced flocculation have not yet been fully investigated and more research is needed in this area (Park et al. 2011). As with extreme $\mathrm{pH}$, flocculation induced by environmental modification may cause micro-algal damage and death and could be unreliable and uneconomic on a commercial scale (Benemann and Oswald 1996; Lee et al. 2009).

Bio-flocculant can be produced by bacteria and bacteria can cause the flocculation of micro-algae (Shelef et al. 1984a). Bio-flocculants produced from bacteria have been shown to be effective in the flocculation of Chlorella (Molina Grima et al. 2003). Bacteria have also been found to flocculate Pleurochrysis carterae, but a relatively high organic carbon content in the growth medium $(0.01 \%)$ is required to grow the bacteria to flocculate the microalgae; approximately $20 \%$ of the carbon content in the growth media from the micro-algae $(0.05 \%)$ (Lee et al. 2009). Bacteria can make up to $30 \%$ of the biomass in the photic zone of open waters (Sournia 1978), and a large proportion of the mixed micro-algal biomass grown in wastewater. Many micro-algal species dominant in wastewater treatment 
HRAPs often form large colonies (Park et al. 2011). Effective separation of algae by sedimentation due to their incorporation into biomass flocs has been demonstrated in symbiotic algal-bacterial wastewater treatment (Medina and Neis 2007). The use of bacteria grown on waste or wastewater could hold the possibility of a low fossil fuel input method of separating micro-algae, especially if energy within the bacterial biomass could be recovered with that of the microalgae. Microalgal bacterial floc from the secondary treatment of sewage supplemented by flue gas from a coal power plant has recently been shown to settle readily, removing $97.5 \%$ of the biomass from the growth medium within 30 minutes and producing a sediment of $2 \%$ bacterial-micro-algal dry biomass (Van den Hende et al. 2011).

Electro-coagulation-flocculation using sacrificial aluminium or iron anodes has been shown to be effective at a 1-litre bench scale in the flocculation of Chlorella and Phaedactylum, with aluminium anodes being superior to iron anodes (Vandamme et al. 2011). Power consumption was favourable in comparison to centrifugation, at between 0.3 and $2 \mathrm{kWh} \mathrm{kg}^{-1}$ with the lowest energy consumption in salt water, suggesting that electro-coagulation may be a "particularly attractive method for harvesting of marine micro-algae" (Vandamme et al. 2011). Aluminium concentration in the micro-algal biomass and growth medium for recycling was lower than with the use of alum. Although electrocoagulation- flocculation may be a promising technology there are concerns about increased power consumption in scale-up as the distance between electrodes greatly influences power consumption (Vandamme et al. 2011).

In electrolytic flocculation non-sacrificial anodes are used and negatively charged algae move towards the anode where the negative charge is lost enabling flocs to be formed (Poelman et al. 1997). This has the advantage that flocculants are not always required, but the electrodes are prone to fouling (Uduman et al. 2010). Electrolytic flocculation has been shown to be effective at a bench scale removing $95 \%$ of the original micro-algae in suspension with an energy consumption of 0.3 $\mathrm{kWh} \mathrm{m}^{-3}$ (Poelman et al. 1997). Ultrasound has also been found to flocculate algae but concentration factors are lower than for other methods with a maximum increase in concentration of twenty times the feed concentration (Bosma et al. 
2003). Electro-coagulation-flocculation, electrolytic flocculation and ultrasonic flocculation have been shown to flocculate micro-algae, but there are disadvantages with each method and none has yet appears to have been demonstrated on a commercial scale.

A wide range of flocculants are available, but there is currently no single flocculant or flocculation method suitable for all types of micro-algae, and the flocculation of marine micro-algae on an industrial scale has yet to be satisfactorily resolved. Sedimentation and flocculation appeared to offer potentially the lowest energy input. A very high energy usage has been reported, however, of $14.8 \mathrm{kWh} \mathrm{m}^{-3}$ for a suspension of Tetraselmis, a marine micro-alga, using a synthetic cationic polyelectrolyte polymer: a greater energy use per cubic metre than centrifugation or filtration (Danquah et al. 2009).

Another method that could be considered for the increasing of the particle size to be harvested is by the use of micro-algal predators. Larger predators could consume the micro-algae and be more easily harvested than the micro-algae. The conversion of plant biomass to animal biomass is inefficient, however, due to energy losses from respiration and other metabolic processes and it appears unlikely that this method will be a viable commercial option for micro-algal biofuel.

\section{Flotation}

Flotation can be relatively fast compared to sedimentation for a number of microalgal species (Edzwald 1993; Oswald 1988; Singh et al. 2011). Although some micro-algae naturally float to the surface, flotation can be promoted by addition of air bubbles (Singh et al. 2011). As with micro-algal sedimentation, the addition of flocculants is required in most cases for flotation to be effective (Edzwald 1993; Mohn 1988). Flocculation flotation was found to be superior to sedimentation for the separation of a marine micro-alga, Isochrysis galbana, but only when large strong flocs were formed by the addition of a combination of organic and inorganic polymers (Shelef et al. 1984b). The reduced density of micro-algal flocs compared to micro-algal cells could favour flotation over sedimentation as a method of separating flocculated micro-algae. The concentration of micro-algae in 
the separated suspension from flotation separation (7\%) is generally higher than micro-algal suspension from sedimentation (Mohn 1988; Oswald 1988).

Flotation processes are classified according to the method of bubble production: dissolved air flotation, electrolytic flotation and dispersed air flotation (Shelef et al. 1984a). Flocculation and froth flotation has been found to be effective in the removal of micro-algae from wastewater using fine air bubbles (no dimensions given) generated by a sparger with gas pressure of 3 atmospheres (Moraine et al. 1979).

Dissolved air flotation (DAF) is a process where small bubbles are generated, with a mean size of $40 \mu \mathrm{m}$ and ranging from 10 to $100 \mu \mathrm{m}$ (Edzwald 1993). Most wastewater treatment lagoons in the USA do not harvest algae, but at plants that do, chemical coagulation followed by dissolved air flotation (DAF) is the most common method; the micro-algae removal is for purification of effluent, however, rather than for micro-algal biomass production (Christenson and Sims 2011). DAF has been found to be effective for harvesting of micro-algae grown on pig slurry, but a high dosage of alum $\left(0.3 \mathrm{~g} \mathrm{l}^{-1}\right)$ was required (Goh 1984). Unfortunately DAF although an efficient flotation option, is energy intensive due to the high pressure required (Hanotu et al. 2012).

Electro-flotation has been found to be effective at a bench scale on a range of micro-algae, but as with DAF it is energy intensive (Shelef et al. 1984a) and not the 'best choice for micro-algal recovery' (Uduman et al. 2010). Oswald (1988) suggested that it could be more useful in salt rather than fresh water. OriginOil developed a process called Quantum Fracturing ${ }^{\mathrm{TM}}$, in which pulsed electromagnetic fields and $\mathrm{pH}$ modification fracture the micro-algal cells with lipid floating to the surface and the remaining micro-algal biomass settling out (Gouveia 2011), but there appears to be little independent published information on energy consumption.

Micro-bubble generation by fluidic oscillation is a method for generating small bubbles using less energy than traditional methods, developed at the University of Sheffield (Zimmerman et al. 2009). Micro-bubbles generated by fluidic oscillation 
have recently been shown to be effective in the recovery of algal biomass from growth medium (Hanotu et al. 2012). Considerably more research is required, however, to establish whether an energy-efficient large-scale fluidic oscillation micro-bubble method for micro-algae harvesting is practicable.

Flotation can have high investment and operational costs and high energy usage (Mohn 1988) especially if small bubbles are required. It has been suggested that the cost of flotation can be as great or greater than centrifugation when the cost of flocculants are included (Mohn 1988) and a recent review has concluded that there is little evidence of the technical or economic feasibility of flotation (Brennan and Owende 2010).

\section{Filtration}

Many types of filters have been used to harvest algae and filtration has been found satisfactory at recovering relatively large algal cells (Molina Grima et al. 2003); but can be hampered by low throughput and rapid clogging (Mohn 1988; Oswald 1988). Although there is a wide a variety of filter designs, membrane filters can be simply classified by the pore or membrane size; macro filtration $>10 \mu \mathrm{m}$, microfiltration 0.1 to $10 \mu \mathrm{m}$, ultrafiltration 0.02 to $0.2 \mu \mathrm{m}$ and reverse osmosis $<0.001 \mu \mathrm{m}$. The pressure to force fluid through a membrane, and therefore the operational energy required, generally increases with reducing membrane pore size. As the size range of micro-algae is typically between 2 and $30 \mu \mathrm{m}$ (Brennan and Owende 2010; Molina Grima et al. 2003) this would suggest that microfiltration has the most appropriate pore size for the majority of common species such as Chlorella and Cyclotella at 5-6 $\mu \mathrm{m}$ in diameter (Edzwald 1993); while and macro filtration is the most appropriate for flocculated cells and larger cells. Filtration of Isochrysis galbana has shown that a pore size of less than $1.5 \mu \mathrm{m}$ is required to remove 'most' marine micro-algal cells from suspension, but on flocculation a pore size of $25 \mu \mathrm{m}$ was found to be effective (Shelef et al. 1984b).

Micro-filtration has been used for the recovery of micro-algal cells for aquaculture, but membrane filtration has not been widely used for producing micro-algal biomass on a large scale and could be less economic than centrifugation at commercial scale (Molina Grima et al. 2003). 
Ultrafiltration is a possible alternative for recovery, in particular of very fragile cells, but has not been generally used for microalgae (Mata et al. 2010; Molina Grima et al. 2003), and operating costs are high and maintenance costs very high (Mata et al. 2010; Purchas 1981). It has been suggested that ultra-filtration of micro-algae will develop in a similar way to desalination of sea water by reverse osmosis, and that the energy input of an optimised micro-algal ultrafiltration plant could be $3 \mathrm{kWh} \mathrm{m}^{-3}$, equivalent to the lowest current energy usage in reverse osmosis desalination (Gouveia 2011). Extracellular organic matter has been reported to lead to rapid clogging of ultrafiltration membranes in the filtration of Spirulina (Rossi et al. 2004). An ultrafiltration membrane with $0.03 \mu \mathrm{m}$ pore size has been used to harvest micro-algae grown on carbon dioxide emissions from a semi-conductor manufacturing plant (Avanti Membrane Technology, Inc. private communication 2012). Average permeate flux was $701 \mathrm{~m}^{-2}$ hour ${ }^{-1}$, but although $95 \%$ of the micro-algae were recovered the concentration factor was only 20 and additional means of concentration are required for further processing. Energy consumption is believed to be range between 1 to $3 \mathrm{kWh} \mathrm{m}^{-3}$ (Avanti Membrane Technology, Inc. private communication 2012).

A wide range of macro-filtration units are available and have been used for water treatment. Vibrating screens were able to separate Coelastrum and Spirulina, although not considered to be the optimum method for Spirulina (Mohn 1988). The energy cost to produce $6 \%$ dry weight of micro-algae has been estimated at $0.4 \mathrm{kWh} \mathrm{m}^{-3}$ (Van den Hende et al. 2011).

Filter presses have found wide application in industry due to the simple design, flexibility and capability to handle a wide range of slurries, and have been used to reduce the number of bacteria and yeast in wine (Brennan et al. 1969; Richardson et al. 2002). Although the equipment is relatively cheap, labour costs can be high and cake washing is not always effective (Brennan et al. 1969; Richardson et al. 2002). A modified filter press with plastic diaphragms that inflate to remove the micro-algae from the filter membrane has been found to be effective in the filtration of Scenedesmus, but capital cost are approximately one third higher than conventional filter presses and pre-coating of membrane with starch was required to prevent clogging (Mohn 1988). 
Rotary vacuum filters are a common filter design (Brennan et al. 1969; Richardson et al. 2002) and have been used to dewater organic sludge from anaerobic digestion (Bailey and Ollis 1977; Srinivas 2008). Coelastrum, a microalga that forms small colonies, can be filtered to a cake containing $18 \%$ dry weight solids without a filter pre-coat, but filtration rates fall rapidly and high energy inputs are required making this not recommended for micro-algal recovery (Mohn 1988). Filter aids have also been required for filtration of Penicillium and Streptomyces mycelia by rotary vacuum filter presses (Bailey and Ollis 1977). Vacuum belt filters can filter larger or colonial micro-algae, but investment and energy costs are very high (Mohn 1988). Larger species of micro-algae such as Spirulina and Micractinium have been found to filter on a rotary vacuum filter with a $12 \mu \mathrm{m}$ pore diameter yielding a 1-3\% dry weight micro-algal slurry, but smaller species of micro-algae such as Chlorella did not filter effectively even if the pore size was reduced to $5 \mu \mathrm{m}$ (Goh 1984).

Belt filters are widely used in the water treatment industry and have been suggested as suitable for separation of Spirulina (Mohn 1988). Large micro-algae have been reported as readily filtered to a concentration of $18 \%$ dry weight if the belt filter press is feed with pre-concentrated algae at $4 \%$, with an energy consumption of $0.5 \mathrm{kWh} \mathrm{m}^{-3}$ (Molina Grima et al. 2003). A three-belt filter is used by Thames Water, UK to remove sludge from an activated sludge wastewater treatment plant. The sludge suspension is first settled in a large conical settler to $0.6 \%$ dry solids and then feed to the belt filter press together with a low dose of polyelectrolyte flocculant, and first gravity filtered to over $6 \%$ dry solids and then further dewatered in the rotary belt filter to up to $25 \%$ (Thames Water private communication 2012). Such a process could be envisioned for harvesting micro-algae. The price of a three belt "Klampress" is approximately $£ 360,000$ to process $80 \mathrm{~m}^{3}$ hour $^{-1}$ with estimated power consumption of 17 to 21 kW (Ashbrook Simon Hartley private communications 2009 and 2012), equivalent to an energy input of $\sim 0.25 \mathrm{kWh} \mathrm{m}^{-3}$.

Two extensive reviews of the filtration of micro-algae have concluded that filtration methods are suitable for micro-algae with larger cells, but inadequate to 
recover micro-algal species with diameters of less than $10 \mu \mathrm{m}$ (Molina Grima et al. 2003; Uduman et al. 2010). Filter aids and flocculants would both appear to assist filtration and reduce equipment operational energy requirements, but additional materials increase costs and may need to be removed from the microalgal biomass and the spent micro-algal growth medium. Ultrafiltration is capable of the removal of small microalgae, but its use is limited by high energy input and low output micro-algal suspension concentrations. Flocculation and belt filtration has been successfully used in the water treatment industry as an effective low-cost separation method for microbial biomass and could be a viable method for the large scale separation of micro-algae, but requires further investigation.

\section{Centrifugation}

In centrifugation, gravity is replaced as the force driving separation by a much greater force. Almost all types of microalgae can be separated reliably and without difficulty by centrifugation (Mohn 1988).

In the case of disc stack centrifuges the force applied may be from 4000 to 14000 times gravitational force (Perry and Chilton 1973), thus greatly reducing separation time. Disc stack centrifuges are the most common industrial centrifuge and are widely used in commercial plants for high value algal products and in algal biofuel pilot plants (Molina Grima et al. 2003). A disc stack centrifuge consists of a relatively shallow cylindrical bowl containing a number (stack) of closely spaced metal cones (discs) that rotate. The mixture to be separated is fed to the centre of the stack of discs and the dense phase travels outwards on the underside of the discs while the lighter phase is displaced to the centre. Materials of different densities are thus separated into thin layers, and the narrow flow channel of $0.4 \mathrm{~mm}$ to $3 \mathrm{~mm}$ between the closely-spaced discs means that the distance materials must travel for this separation to occur is small (Mannweiler and Hoare 1992; Perry and Chilton 1973). Disc stack centrifuges are ideally suited for separating particles of the size $(3-30 \mu \mathrm{m})$ and concentration $(0.02$ to $0.05 \%)$ of algal cells in a growth medium, as shown in Figure 1. They can separate not only solid/liquid, but also liquid/liquid or liquid/liquid/solid on a continuous basis. 


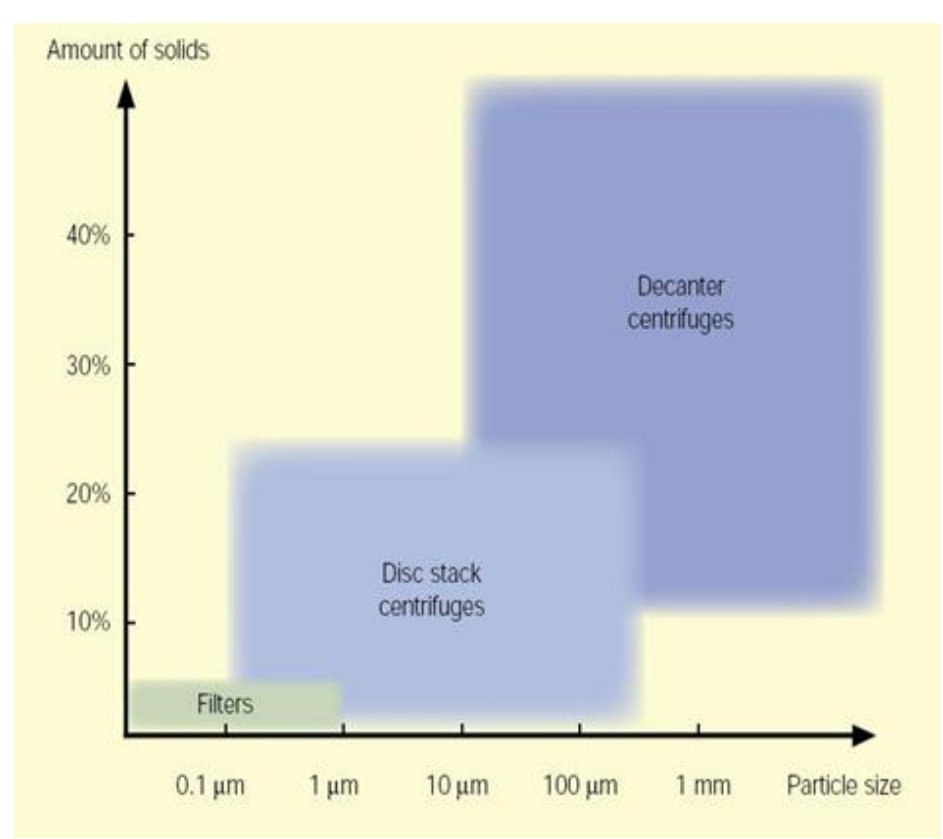

Figure 1 Centrifuge Application Graph; Particle Sizes and Concentration Range. Courtesy Alfa Laval

Disc stack centrifuges generally have high energy consumption (Uduman et al. 2010). As an example, a Westfalia HSB400 disc-bowl centrifuge with intermittent self-cleaning bowl centrifugal clarifier has a maximum capacity of $95 \mathrm{~m}^{3}$ hour $^{-1}$, but is limited to $35 \mathrm{~m}^{3}$ hour ${ }^{-1}$ for algae harvesting (Cawdery, D, GEA Westfalia, personal communication, 2009). The maximum power of the motor is $75 \mathrm{~kW}$, but normal operating demand is probably around $50 \mathrm{~kW}$, giving an energy cost for separation of $1.4 \mathrm{kWh} \mathrm{m}^{-3}$ (Cawdery, D, GEA Westfalia, personal communication, 2009). A value of $1 \mathrm{kWh} \mathrm{m}^{-3}$ has been reported for concentrating Scenedesmus from $0.1 \%$ to $12 \%$ using a Westfalia self-cleaning disk stack centrifuge (Molina Grima et al. 2003) and an energy consumption of $1.4 \mathrm{kWh} \mathrm{m}^{-3}$ has been reported for the disc bowl centrifuge harvesting of micro-algae grown on pig waste (Goh 1984). If a HSB400 centrifuge is fed with a suspension of $0.02 \%$ dry weight of microalgae having an oil content of $20 \%$, this would yield the equivalent $7 \mathrm{~kg}$ of dry algal material per hour and $1.4 \mathrm{~kg}$ of algal oil. If $90 \%$ of the algal oil is converted to methyl ester biodiesel then $1.26 \mathrm{~kg}$ is produced with a calorific value of $13 \mathrm{kWh}$, assuming a net calorific value $10.33 \mathrm{kWh} \mathrm{kg}^{-1}$ (DEFRA 2010; Milledge and Heaven 2011). The operating energy for centrifugation is thus approximately four times the energy available in the algal biodiesel. Although this calculation is based on the data from one manufacturer, similar information for Alfa-Laval models (Ord, D., Alfa Laval, personal 
communication, 2009) also indicates that more energy is used in centrifugation than is available in the biodiesel produced.

This simple calculation together with other studies (Ferrell and Sarisky-Reed 2010; Molina Grima et al. 2003) indicates the high energy usage of disc stack centrifuges. The energy return using centrifugation could be improved by: preconcentration using a combination of separation techniques; use of the entire algal biomass rather than just the lipid fraction for energy production; or the use of the centrifuge to eliminate other energy consuming unit operations in algal biofuel production process. Pre-concentration, by settlement or other low energy methods, to $0.5 \%$ (algal dry weight) could improve the energy balance, but would still require $15 \%$ of the energy in the biodiesel product for centrifugation (Milledge and Heaven 2011).

Solid Bowl centrifuges were found not to be superior to disc-bowl centrifuges in the recovery of micro-algae grown on pig waste (Goh 1984). Decanter centrifuges have been found to be as effective as solid bowl centrifuges for separating microalgae (Goh 1984), but the energy consumption of decanter centrifuges is higher than that of disc bowl centrifuges at $8 \mathrm{kWh} \mathrm{m}^{-3}$ (Molina Grima et al. 2003). Decanter centrifuges can produce a more concentrated output than disc bowl centrifuges, but as can be seen in Figure 1 they are better suited to higher solid suspensions than those generated by micro-algal growth ponds (Brennan et al. 1969; Mohn 1988; Perry and Chilton 1973; Purchas 1981). It is suggested that decanter centrifuges could be useful for the further concentration of micro-algal slurries from other harvesting methods (Goh 1984; Molina Grima et al. 2003).

Hydro-cyclones, although relatively low energy $\left(0.3 \mathrm{kWh} \mathrm{m}^{-3}\right)$ compared to other harvesting methods, are reported to be an unreliable means of concentrating micro-algae as they only achieve a maximum concentration $0.4 \%$ with a concentration factor of 4 (Molina Grima et al. 2003). The advantage of hydrocyclones for micro-algal separation has been given as low capital costs, but the disadvantages are that they can only process a limited number of micro-algal strains and efficiency is highly dependent on solids concentration (Origin Oil 2010). Hydro-cyclones have been found to disrupt natural floc of the marine 
micro-algae Phaeocystis (Veldhuis et al. 2006), and may also break up microalgal flocs, increasing subsequent harvesting difficulties. It would appear that if hydro-cyclones have a role in the harvesting of micro-algae it will be limited to pre-concentration of micro-algae prior to another harvesting method.

In a new type of spiral plate centrifuge, manufactured by Evodus, the suspension flows outwards in thin films over vertical plates with the solid sediment or microalgae being forced by centrifugal force to collecting on the outer bottom edge of the vanes. Work by Evodus with the James Cook University in Australia suggests a $0.025 \%$ suspension of Nannochloropsis can be harvested to a micro-algal paste of $31.5 \%$ dry weight for an energy usage of $1.9 \mathrm{kWh} \mathrm{kg}^{-1}$ of dried algae, equivalent to $34 \%$ of the total energy within the micro-algae (Evodus private communication 2011). This energy requirement is considerably below that calculated for the harvesting of algae by disc stack centrifugation (Milledge and Heaven 2011), but the discharge of the harvested algae is not continuous and current maximum throughput is limited to $4 \mathrm{~m}^{3}$ hour ${ }^{-1}$. Evodus report that trials are continuing in both commercial and research organisations (Evodus private communication 2011).

The energetic position of using centrifugation for the production of biofuel could be improved by the use of the entire algal biomass (Milledge 2010a) A kilogram of dry algal biomass containing $20 \%$ oil would yield around $1.9 \mathrm{kWh}$ of biodiesel, but the calorific value of the entire biomass is around $6 \mathrm{kWh}$ (Milledge $2010 \mathrm{~b}$ ) and the exploitation of the entire biomass could thus be a key factor in a positive energy balance in the production of biofuel (Heaven et al. 2011; Sialve et al. 2009; Milledge 2010a; Stephenson et al. 2010).

\section{Materials Handling}

The harvesting of micro-algae is one stage in the process of the production of micro-algal biofuel and the harvesting operation must be linked to both a growth system and a method of exploiting the energy within the micro-algal organic matter. The energy costs of moving materials between process operations could be considerable, especially for the flow of the dilute micro-algal suspension from the growth system and for the recycling of the growth media after harvesting. In an 
outline design developed for Pure Energy Fuels for the production of micro-algal biodiesel the energy required for the movement and recycling of material between major unit operations was estimated to be as great as or greater than the operational energy for the mixing and gaseous transfer in micro-algal raceway growth ponds.

The physical properties of the micro-algal suspension vary with concentration and may influence subsequent treatment and handling. A 1 to $2 \%$ suspension is milklike, a 10-12\% suspension cream like and a 15-20\% cheese like (Oswald 1988). At concentrations above $7 \%$ the micro-algal suspensions become non-Newtonian, potentially increasing handling problems; and at 15-20\% the micro-algal suspension may no longer be fluid further increasing handling difficulties (Greenwell et al. 2010).

\section{Drying}

In addition to harvesting drying may be required prior to energy extraction. The removal of water from the algal biomass by evaporation can be very energy intensive. The enthalpy of water at $20^{\circ} \mathrm{C}$ is $84 \mathrm{~kJ} \mathrm{~kg}^{-1}$ (Weast 1985) and the enthalpy of steam at $100^{\circ} \mathrm{C}$ is $2676 \mathrm{~kJ} \mathrm{~kg}^{-1}$ (Mayhew and Rogers 1972): therefore to heat and evaporate water at atmospheric pressure from a temperature of $20{ }^{\circ} \mathrm{C}$, requires an energy input of approximately $2.6 \mathrm{MJ} \mathrm{kg}^{-1}$ or over $700 \mathrm{kWh} \mathrm{m}^{-3}$. A variety of methods have been used to dry micro-algae subsequent to further processing or energy extraction: solar drying, roller drying, spray drying and freeze drying. Solar drying does not require fossil fuel energy, but is weather dependent and can cause considerable denaturisation of organic compounds. Solar drying is the least expensive drying option (Brennan and Owende 2010), but large areas are required as only around a $100 \mathrm{~g}$ of dry matter can be produced from each square metre of sun-drier surface (Oswald 1988). Roller, spray and freeze driers have been widely used in the food industry and have all produced satisfactory result in the drying of Dunaliella (Molina Grima et al. 2003). Spray drying has been the preferred method of drying high value micro-algal products but is expensive (Brennan and Owende 2010; Molina Grima et al. 2003; Oswald 1988) and probably uneconomic for the production of micro-algal biofuels. Although spray drying can produce a dark green powder (Oswald 1988) it can cause 
significant deterioration of micro-algal pigments (Brennan and Owende 2010; Molina Grima et al. 2003). Freeze drying tends to cause less damage to organic materials than spray drying, but is more expensive (Brennan et al. 1969) and is typically used for products such as premium instant coffee to give a better flavour than spray dried coffee. The use of freeze dying is considered too expensive for the large-scale commercial recovery of micro-algae and its use is confined to research (Molina Grima et al. 2003).

Dewatering during harvesting uses less energy than evaporation to remove water and it would appear preferable to minimise the water content of the harvested micro-algae prior to drying and select energy extraction methods that do not necessitate the need for drying of the micro-algae.

\section{Conclusions}

Sedimentation and flocculation potentially offer the lowest energy input for micro-algal harvesting, but there appears to be no one method or combination of harvesting methods suited to all micro-algae. The concentration of the microalgae from the various harvesting methods can vary from $0.5 \%$ to $27 \%$ dry weight, and further dewatering or drying may be required prior to energy extraction from the micro-algae. The degree of concentration required will vary with the method used to produce useable energy from the micro-algae. The most energy-efficient method of harvesting or of producing useable energy from micro-algae may not be part of the most overall energy efficient micro-algal biofuel production process. The most energy efficient micro-algal biofuel process could consist of a growth system that does not give the maximum yield, but results in a more easily harvested micro-algal biomass, and an energy extraction process that requires the minimum concentration by the micro-algal harvesting method. If efficient harvesting is, as many researchers consider, the major challenge of commercialising micro-algal biofuel it will have a considerable influence on the design and operation of both upstream and downstream processes in an overall micro-algal biofuel production process.

\section{References}


Amer L, Adhikari B, Pellegrino J (2011) Technoeconomic analysis of five microalgae-to-biofuels processes of varying complexity. Bioresource Technology 102 (20):9350-9359. doi:10.1016/j.biortech.2011.08.010

Bailey JE, Ollis DF (1977) Biochemical Engineering Fundamentals. McGraw Hill, New York

Benemann J, Koopman B, Weissman J, Eisenberg D, Goebel R (1980) Development of microalgae harvesting and high-rate pond technologies in California. In: Shelef G, Soeder CJ (eds) Algae Biomass. Elsevier, Amsterdam,

Benemann J, Oswald WJ (1996) Systems and economic analysis of microalgae ponds for conversion of CO2 to Biomass. Pittsburgh Energy Technology Centre, Pittsburgh

Benemann J, Weissman JC, Koopman BL, Oswald WJ (1977) Energy-production by microbial photosynthesis. Nature 268 (5615):19-23

Bienfang PK (1981) Sinking rates of heterogeneous temperate phytoplankton populations. J Plankton Res 3 (2):235-254

Bosma R, van Spronsen WA, Tramper J, Wijffels RH (2003) Ultrasound, a new separation technique to harvest microalgae. J Appl Phycol 15 (2-3):143153. doi:10.1023/a:1023807011027

Brennan JG, Butters JR, Cowell ND, Lilly AEV (1969) Food Engineering Operation. Elsevier, London

Brennan L, Owende P (2010) Biofuels from microalgae--A review of technologies for production, processing, and extractions of biofuels and co-products. Renewable and Sustainable Energy Reviews 14 (2):557-577. doi:DOI: 10.1016/j.rser.2009.10.009

Choi SK, Lee JY, Kwon DY, Cho KJ (2006) Settling characteristics of problem algae in the water treatment process. Water Sci Technol 53 (7):113-119. doi:10.2166/wst.2006.214

Christenson L, Sims R (2011) Production and harvesting of microalgae for wastewater treatment, biofuels, and bioproducts. Biotechnol Adv 29 (6):686-702. doi:10.1016/j.biotechadv.2011.05.015

Cole TM, Wells SA (1995) CE-QUAL-W2. A two dimensional, laterally averaged, hydrodynamic \& water quality model, Version 3.5: User Manual. US Army Corps Engineers, Vicksburg MS

Collet P, Hélias A, Lardon L, Ras M, Goy R-A, Steyer J-P (2011) Life-cycle assessment of microalgae culture coupled to biogas production. Bioresource Technology 102 (1):207-214. doi:DOI: 10.1016/j.biortech.2010.06.154

Danquah MK, Ang L, Uduman N, Moheimani N, Fordea GM (2009) Dewatering of microalgal culture for biodiesel production: exploring polymer flocculation and tangential flow filtration. J Chem Technol Biotechnol 84 (7):1078-1083. doi:10.1002/jctb.2137

DEFRA (2010) Guidelines to Defra / DECC's GHG Conversion Factors for Company Reporting. Produced by AEA for the Department of Energy and Climate Change (DECC)and the Department for Environment, Food and Rural Affairs (Defra), LONDON

Edzwald JK (1993) Algae, bubbles, coagulants, and dissolved air flotation. Water Sci Technol 27 (10):67-81

Elliott A (2006) Substitution of ferric chloride with Magnafloc 1597 in autothermal thermophyllic aerated digestion (ATAD )sludge de-watering 
processes. Paper presented at the 69th Annual Water Industry Engineers and Operators' Conference, Bendingo, Australia,

Ferrell J, Sarisky-Reed V (2010) National Algal Biofuels Technology Roadmap. A technology roadmap resulting from the National Algal Biofuels Workshop U.S. Department of Energy, Office of Energy Efficiency and Renewable Energy, Biomass Program. available online @ http://www1.eere.energy.gov/biomass/pdfs/algal_biofuels_roadmap.pdf, Washington

Goh A Production of microalgae using pig waste as a substrate. In: Barclay WR, McIntosh RP (eds) Algal Biomass Technologies, Colorado, 1984. J Cramer,

Gouveia L (2011) Microalgae as a feedstock for biofuels. Springer, Heidelberg

Granados MR, Acién FG, Gómez C, Fernández-Sevilla JM, Molina Grima E (in press) Evaluation of flocculants for the recovery of freshwater microalgae. Bioresource Technology

Greenwell HC, Laurens LML, Shields RJ, Lovitt RW, Flynn KJ (2010) Placing microalgae on the biofuels priority list: a review of the technological challenges. Journal of the Royal Society Interface 7 (46):703-726. doi:10.1098/rsif.2009.0322

Hanotu J, Bandulasena HCH, Zimmerman WB (2012) Microflotation performance for algal separation. Biotechnology and Bioengineering:n/an/a. doi:10.1002/bit.24449

Harith ZT, Yusoff FM, Mohamed MS, Din MSM, Ariff AB (2009) Effect of different flocculants on the flocculation performance of microalgae, Chaetoceros calcitrans, cells. Afr J Biotechnol 8 (21):5971-5978

Heaven S, Milledge J, Zhang Y (2011) Comments on 'Anaerobic digestion of microalgae as a necessary step to make microalgal biodiesel sustainable'. Biotechnol Adv 29 (1): 164-167. doi:DOI: 10.1016/j.biotechadv.2010.10.005

Hendricks D (2010) Fundamentals of Water Treatment Unit Processes: Physical, Chemical, and Biological. CRC Press, Boca Raton, FL

Jago CF, Kennaway GM, Novarino G, Jones SE (2007) Size and settling velocity of suspended flocs during a Phaeocystis bloom in the tidally stirred Irish Sea, NW European shelf. Marine Ecology-Progress Series 345:51-62. doi:10.3354/meps07006

Knuckey RM, Brown MR, Robert R, Frampton DMF (2006) Production of microalgal concentrates by flocculation and their assessment as aquaculture feeds. Aquac Eng 35 (3):300-313. doi:10.1016/j.aquaeng.2006.04.001

Kromkamp J, Walsby AE (1990) A computer-model of buoyancy and vertical migration in cyanobacteria. J Plankton Res 12 (1):161-183

Lee A, Lewis D, Ashman P (2009) Microbial flocculation, a potentially low-cost harvesting technique for marine microalgae for the production of biodiesel. J Appl Phycol 21 (5):559-567. doi:10.1007/s10811-008-9391-8

Lundquist TJ, Woertz IC, Quinn NWT, Benemann JR (2010) A Realistic Technology and Engineering Assessment of Algae Biofuel Production. Energy Biosciences Inst, Berkeley, California

Mannweiler K, Hoare M (1992) The scale-down of an industrial disk stack centrifuge. Bioprocess Eng 8 (1-2):19-25. doi:10.1007/bf00369259 
Mata TM, Martins AA, Caetano NS (2010) Microalgae for biodiesel production and other applications: A review. Renew Sust Energ Rev 14 (1):217-232. doi:10.1016/j.rser.2009.07.020

Mayhew YR, Rogers GFC (1972) Thermodynamic and Transport Properties of Fluids. Blackwell, Oxford

Medina M, Neis U (2007) Symbiotic algal bacterial wastewater treatment: effect of food to microorganism ratio and hydraulic retention time on the process performance. Water Sci Technol 55 (11):165-171. doi:10.2166/wst.2007.351

Milledge JJ (2010a) The challenge of algal fuel : economic processing of the entire algal biomass. Condensed Matter -Materials Engineering Newsletter $1(6): 4-6$

Milledge JJ (2010b) The potential yield of microalgal oil. Biofuels International 4 (2):44 45

Milledge JJ, Heaven S (2011) Disc Stack Centrifugation Separation and Cell Disruption of Microalgae: A Technical Note. Environment and Natural Resources Research 1 (1):17-24. doi:10.5539/enrr.v1n1p17

Millero FJ, Lepple FK (1973) The density and expansibility of artificial seawater solutions from 0 to $40^{\circ} \mathrm{C}$ and 0 to 21 [per mille sign] chlorinity. Marine Chemistry 1 (2):89-104. doi:Doi: 10.1016/0304-4203(73)90009-1

Mohn F (1988) Harvesting of micro-algal biomass. In: Borowitzka MA, Borowitzka LJ (eds) Micro-algal Biotechnology Cambridge University Press, Cambridge,

Molina Grima E, Belarbi E-H, Acien-Fernandez FG, Robles-Medina A, Yusuf C (2003) Recovery of microalgal biomass and metabolites: process options and economics. Biotechnol Adv 20 (7-8):491-515

Moraine R, Shelef G, Meydan A, Levi A (1979) Algal single cell protein from wastewater-treatment and renovation process. Biotechnology and Bioengineering 21 (7):1191-1207

Nurdogan Y, Oswald WJ (1996) Tube settling of high-rate pond algae. Water Sci Technol 33 (7):229-241

Olguín EJ (2003) Phycoremediation: key issues for cost-effective nutrient removal processes. Biotechnol Adv 22 (1-2):81-91. doi:Doi: 10.1016/s0734-9750(03)00130-7

Origin Oil (2010) Algae Harvesting, Dewatering and Extraction. Paper presented at the World Biofuel Markets, Amsterdam,

Oswald WJ (1988) Large-scale algal culture systems (engineering aspects). In: Borowitzka MA, Borowitzka LJ (eds) Micro-algal Biotechnology. Cambridge University Press, Cambridge,

Packer M (2009) Algal capture of carbon dioxide; biomass generation as a tool for greenhouse gas mitigation with reference to New Zealand energy strategy and policy. Energy Policy 37 (9):3428-3437. doi:DOI: 10.1016/j.enpol.2008.12.025

Papazi A, Makridis P, Divanach P (2010) Harvesting Chlorella minutissima using cell coagulants. J Appl Phycol 22 (3):349-355. doi:10.1007/s10811-0099465-2

Park JBK, Craggs RJ, Shilton AN (2011) Wastewater treatment high rate algal ponds for biofuel production. Bioresource Technology 102 (1, Sp. Iss. SI):35-42. doi:10.1016/j.biortech.2010.06.158 
Peperzak L, Colijn F, Koeman R, Gieskes WWC, Joordens JCA (2003)

Phytoplankton sinking rates in the Rhine region of freshwater influence. $\mathrm{J}$

Plankton Res 25 (4):365-383

Perry RH, Chilton CH (1973) Chemical Engineers' Handbook. Fifth edn. McGraw Hill, Tokyo

Poelman E, De Pauw N, Jeurissen B (1997) Potential of electrolytic flocculation for recovery of micro-algae. Resources, Conservation and Recycling 19 (1):1-10. doi:10.1016/s0921-3449(96)01156-1

Purchas DB (1981) Solid-liquid Separation Technology Uplands Press, London

Pushparaj B, Pelosi E, Torzillo G, Materassi R (1993) Microbial biomass recovery using a synthetic cationic polymer. Bioresource Technology 43 (1):59-62. doi:10.1016/0960-8524(93)90083-n

Ras M, Lardon L, Bruno S, Bernet N, Steyer J-P (2011) Experimental study on a coupled process of production and anaerobic digestion of Chlorella vulgaris. Bioresource Technology 102 (1):200-206. doi:DOI: 10.1016/j.biortech.2010.06.146

Reynolds CS (1984) The ecology of freshwater phytoplankton. Cambridge University Press, Cambridge

Richardson JF, Harker JH, Backhurst JR (2002) Coulson \& Richardson's Chemical Engineering; Volume 2, Fifth edition, Particle Technology \& Separation Processes. Elsevier Butterworth-Heinemann, Oxford

Rossi N, Jaouen O, Legentilhomme P, Petit I (2004) Harvesting of cyanobacterium Arthrospira platensis usmg organic filtration membranes. Food Bioprod Process 82 (C3):244-250. doi:10.1205/fbio.82.3.244.44177

Sawayama S, Minowa T, Yokoyama SY (1999) Possibility of renewable energy production and $\mathrm{CO} 2$ mitigation by thermochemical liquefaction of microalgae. Biomass and Bioenergy 17 (1):33-39. doi:Doi: 10.1016/s0961-9534(99)00019-7

Schenk P, Thomas-Hall S, Stephens E, Marx U, Mussgnug J, Posten C, Kruse O, Hankamer B (2008) Second Generation Biofuels: High-Efficiency Microalgae for Biodiesel Production. BioEnergy Research 1 (1):20-43. doi:10.1007/s 12155-008-9008-8

Schlarb-Ridley B (2011) Algal Research in the UK. A Report for BBSRC. BBSRC,

Schlesinger A, Eisenstadt D, Bar-Gil A, Carmely H, Einbinder S, Gressel J (in press) Inexpensive non-toxic flocculation of microalgae contradicts theories; overcoming a major hurdle to bulk algal production. Biotechnol Adv (0). doi:10.1016/j.biotechadv.2012.01.011

Shelef G, Sukenik A, Green M (1984a) Microalgae Harvesting and Processing: A Literature Review. Solar Energy Research Institute, Golden, Colorado

Shelef G, Sukenik A, Green M Separation and harvesting of marine microalgal biomass. In: Barclay WR, McIntosh RP (eds) Algal biomass technology, Colorado, 1984b. J. Cramer,

Shen Y, Yuan W, Pei ZJ, Wu Q, Mao E (2009) Microalgae mass production methods. Trans ASABE 52 (4):1275-1287

Sialve B, Bernet N, Bernard O (2009) Anaerobic digestion of microalgae as a necessary step to make microalgal biodiesel sustainable. Biotechnol Adv 27 (4):409-416. doi:10.1016/j.biotechadv.2009.03.001

Singh A, Nigam PS, Murphy JD (2011) Mechanism and challenges in commercialisation of algal biofuels. Bioresource Technology 102 (1):2634. doi:DOI: 10.1016/j.biortech.2010.06.057 
Şirin S, Trobajo R, Ibanez C, Salvadó J (2012) Harvesting the microalgae; Phaeodactylum tricornutum with polyaluminum chloride, aluminium sulphate, chitosan and alkalinity-induced flocculation. J Appl Phycol:1-14. doi:10.1007/s 10811-011-9736-6

Smayda TJ (1970) The suspension and sinking of phytoplankton in the sea. In: Barnes $\mathrm{H}$ (ed) Oceanography and marine biology annual review, vol 8. George Allen \& Unwin, London, pp 353-414

Sournia A (ed) (1978) Phytoplankton manual. UNESCO, Paris

Speight J (2005) Lange's Handbook of Chemistry. 16 edn. McGraw-Hill

Srinivas T (2008) Environmental biotechnology New Age International New Delhi

Stephenson AL, Kazamia E, Dennis JS, Howe CJ, Scott SA, Smith AG (2010) Life-Cycle Assessment of Potential Algal Biodiesel Production in the United Kingdom: A Comparison of Raceways and Air-Lift Tubular Bioreactors. Energy \& Fuels 24 (7):4062-4077. doi:10.1021/ef1003123

Sukenik A, Bilanovic D, Shelef G (1988) Flocculation of microalgae in brackish and sea waters. Biomass 15 (3):187-199. doi:10.1016/01444565(88)90084-4

Uduman N, Qi Y, Danquah MK, Forde GM, Hoadley A (2010) Dewatering of microalgal cultures: A major bottleneck to algae-based fuels. Journal of Renewable and Sustainable Energy 2 (1):012701-012715

Van den Hende S, Vervaeren H, Desmet S, Boon N (2011) Bioflocculation of microalgae and bacteria combined with flue gas to improve sewage treatment. New Biotech 29 (1):23-31

Van Lerland ET, Peperzak L (1984) Separation of marine seston and density determination of marine diatoms by density gradient centrifugation. J Plankton Res 6 (1):29-44. doi:10.1093/plankt/6.1.29

Vandamme D, Foubert I, Meesschaert B, Muylaert K (2010) Flocculation of microalgae using cationic starch. J Appl Phycol 22 (4):525-530. doi:10.1007/s 10811-009-9488-8

Vandamme D, Pontes SCV, Goiris K, Foubert I, Pinoy LJJ, Muylaert K (2011) Evaluation of Electro-Coagulation-Flocculation for Harvesting Marine and Freshwater Microalgae. Biotechnology and Bioengineering 108 (10):23202329. doi:10.1002/bit.23199

Veldhuis MJW, Fuhr F, Boon JP, Ten Hallers-Tjabbers C (2006) Treatment of ballast water; How to test a system with a modular concept? Environ Technol 27 (8):909-921. doi:10.1080/09593332708618701

Verma NM, Mehrotra S, Shukla A, Mishra BN (2010) Prospective of biodiesel production utilizing microalgae as the cell factories: A comprehensive discussion. Afr J Biotechnol 9 (10):1402-1411

Waite AM, Thompson PA, Harrison PJ (1992) Does energy control the sinking rates of marine diatoms. Limnology and Oceanography 37 (3):468-477

Weast RC (ed) (1985) Handbook of Chemistry and Physics. CRC, Boca Raton Fl

Zamalloa C, Vulsteke E, Albrecht J, Verstraete W (2011) The techno-economic potential of renewable energy through the anaerobic digestion of microalgae. Bioresource Technology 102 (2):1149-1158.

doi:10.1016/j.biortech.2010.09.017

Zimmerman WB, Hewakandamby BN, Tesar V, Bandulasena HCH, Omotowa OA (2009) On the design and simulation of an airlift loop bioreactor with microbubble generation by fluidic oscillation. Food Bioprod Process 87 (3):215-227. doi:DOI: 10.1016/j.fbp.2009.03.006 
